\title{
Tablet misoprostol as a cervical priming agent prior to surgical abortion
}

\author{
Vijaya Manohar Revankar ${ }^{1 *}$, Harsha T. N. ${ }^{2}$ \\ ${ }^{1}$ Department of Obstetrics and Gynecology, KMC, Mangalore, Manipal University, Karnataka, India \\ ${ }^{2}$ Department of Obstetrics and Gynecology, Government Hospital, Madikeri, Karnataka, India
}

Received: 28 April 2017

Accepted: 22 May 2017

\section{*Correspondence:}

Dr. Vijaya Manohar Revankar,

E-mail: vijaya.manohar.revankar@gmail.com

Copyright: () the author(s), publisher and licensee Medip Academy. This is an open-access article distributed under the terms of the Creative Commons Attribution Non-Commercial License, which permits unrestricted non-commercial use, distribution, and reproduction in any medium, provided the original work is properly cited.

\section{ABSTRACT}

Background: Every effort to promote effective contraceptive methods as well as emergency contraception is being made, still there would be a need and place for termination of pregnancy. Objective of present study was to evaluate and to know the efficacy and adverse effects of tablet misoprostol 400 micro gram as a cervical priming agent administered either by oral or vaginal route, 3 hours before MTP.

Methods: Prospective randomized not blinded study carried out for two years at Government Tertiary care level hospital, OBG Department, Mangalore on 100 women with gestational age up to 12 weeks requesting for surgical abortion.

Results: In both the groups there was no significant statistical difference with respect to age ( $\mathrm{p}=0.44)$, parity and gestational age $(\mathrm{p}=0.59)$. With respect to baseline cervical dilatation significant statistical difference was not observed in both the groups. Baseline dilatation of the cervix was $8.0 \mathrm{~mm}$ versus $8.2 \mathrm{~mm}$ (p value=0.55). Baseline cervical dilatation was $\geq 7 \mathrm{~mm}$ in $90 \%$ of women when tab misoprostol was given by oral route and $94 \%$ with vaginal route. There was no significant statistical difference with respect to side effects ( $p$ value $>0.05$ ) except nausea ( $p=0.01)$ found in both the groups. Gastro Intestinal side effects were more in oral misoprostol group, but it was not statistically significant.

Conclusions: Oral route is an effective alternative to vaginal route. Oral route is preferred over vaginal route because women can do self-administration at home and there was no internal examination discomfort.

Keywords: Cervical dilatation, Cervical priming, Misoprostol, Surgical abortion

\section{INTRODUCTION}

Every effort to promote effective contraceptive methods as well as emergency contraception is being made, still there would be a need and place for termination of pregnancy. One of the most import events in woman's life is child bearing and surely women would like to decide how many and when she should have children. Many contraceptive methods are now available to help her to meet her requirement. But contraceptive methods do fail sometimes, and then women find herself with an unwanted pregnancy. MTP act has legalized termination of such unwanted pregnancy in India in 1971.

The method generally used to do early abortion is mechanical dilatation of cervix followed by suction evacuation or dilatation and curettage. With surgical methods common complications associated with mechanical dilation are cervical laceration, uterine perforation, cervical incompetence and recurrent abortions. ${ }^{1,2}$ Therefore, there is overwhelming urge to find a reliable and easier method for cervical dilatation. 
The complications of surgical abortion were less when cervix was primed before surgical abortion. The RCOG also recommends cervical priming is useful before surgical abortion when the pregnant women are less than 18 years and pregnancy was more than 10 weeks. ${ }^{3}$ Various studies conducted to search for appropriate technique and drugs for cervical priming, which should be cheap, easily available with minimal or no complications. At present a synthetic analogue of $\mathrm{PGE}_{1}$ that is misoprostol is more useful as a cervical priming agent since it is freely available, no need to freeze it, ease of administration and cheap. ${ }^{4,5}$

Therefore, the purpose of this study was to use tab misoprostol 400 micro gram for priming of the cervix before MTP upto 12 wks.

\section{METHODS}

Prospective randomised not blinded study done at Govt. Tertiary Care Level Hospital, Mangalore Karnataka for two years.

\section{Inclusion criteria}

- Pregnant women upto 12 weeks of gestation for surgical abortion.

\section{Exclusion criteria}

- History of Heart disease

- History of Allergy to prostaglandins.

Period of gestation was calculated from LMP and confirmed by internal examination and if required by USG. Written informed consent, detailed history and examination was done. 100 pregnant women, were given tab. Misoprostol 400 microgram 3 hours prior to surgical abortion. 50 women were given orally and 50 women received tab Misoprostal vaginally. Dilatation and curettage was done under IV sedation. Dilation of the cervix was assessed by passing Hegar's dilator to start with number 12 size and the dilator which was passed through the os without any resistance was considered as baseline dilatation. Non-sensitized Rh-negative women were given 50 microgram Anti D injection intramuscularly. All adverse effects were noted.

\section{Statistical analysis}

Results were analyzed using SPSS version by Chi Square test, Fisher's exact test, ANOVA (Analysis of Variance). If $\mathrm{p}$ value was $<0.05$ it was considered statistically significant.

\section{RESULTS}

It is observed that in oral group, majority of patients 22 (40\%) were $26-30$ years, followed by 14 (28\%) in $21-25$ years. In vaginal group, majority of patients 20 (40\%) in 21-25 years, followed by 17 (34\%) in26-30 years.

Table 1: Mean age with standard deviation.

\begin{tabular}{|lllll|}
\hline Group & $\begin{array}{l}\text { Mean age } \\
\text { (yrs) }\end{array}$ & SD & $\begin{array}{l}\mathrm{t} \\
\text { value }\end{array}$ & p value \\
\hline Oral & 28.16 & 5.32 & 0.77 & 0.443 \\
\hline Vaginal & 27.36 & 5.06 & & NS \\
\hline
\end{tabular}

Mean age of the patients were 28.16 and 27.36 years for oral and vaginal groups respectively, which is not statistically significant difference $(\mathrm{t}=0.77, \mathrm{p}=0.443)$. (Table 1).

Table 2: Mean period of gestation (weeks) with standard deviation.

\begin{tabular}{|lllll|}
\hline & $\begin{array}{c}\text { Mean } \\
\text { GA }\end{array}$ & $\begin{array}{l}\text { Standard } \\
\text { deviation }\end{array}$ & t & p \\
\hline Oral $(\mathrm{n}=50)$ & 8.03 & 2.06 & \multirow{2}{*}{0.545} & $\begin{array}{l}0.587 \\
\text { Vaginal }(\mathrm{n}=50)\end{array}$ \\
\hline V & 8.08 & 1.97 & & NS \\
\hline
\end{tabular}

Distribution of patients according to gestational age is comparable in both the groups, majority of them 22 $(44 \%)$ in the gestational age $<8$ weeks followed by $8-10$ wks. Mean period of gestation is 8.03 and 8.08 weeks in oral and vaginal groups respectively, which is not statistically significant $(\mathrm{p}$ value $=0.545, \mathrm{p}=0.587)($ Table 2).

Distribution of patients according to gravidity is comparable in both groups. Majority of them were gravida 3.

Table 3: Distribution of patients according to cervical dilation (CD) (mm).

\begin{tabular}{|c|c|c|c|c|c|}
\hline \multirow{3}{*}{$\begin{array}{l}\mathrm{CD} \\
(\mathrm{mm})\end{array}$} & \multicolumn{4}{|c|}{ Group } & \multirow{3}{*}{ Tota } \\
\hline & \multicolumn{2}{|c|}{ Oral $(\mathrm{N}=50)$} & \multicolumn{2}{|c|}{ VAG $(\mathbf{N}=50)$} & \\
\hline & $\mathbf{N}$ & $\%$ & $\mathbf{N}$ & $\%$ & \\
\hline 3 & 2 & 4 & 0 & & 2 \\
\hline 4 & 3 & 6 & 1 & 2 & 4 \\
\hline 5 & 0 & & 2 & 4 & 2 \\
\hline 7 & 8 & 16 & 9 & 18 & 17 \\
\hline 8 & 21 & 42 & 20 & 40 & 41 \\
\hline 9 & 6 & 12 & 9 & 18 & 15 \\
\hline 10 & 8 & 16 & 8 & 16 & 16 \\
\hline \multirow[t]{2}{*}{12} & 2 & 4 & 1 & 2 & 3 \\
\hline & 50 & & 50 & & 100 \\
\hline
\end{tabular}

Distribution of patients according to cervical dilatation is comparable in both the groups. Majority of the patients had cervical dilatation of $8 \mathrm{~mm}$ both in oral $(42 \%)$ and vaginal group (40\%) followed by $7 \mathrm{~mm}$ (oral $16 \%$, vaginal 18\%) and $9 \mathrm{~mm}$ (Oral 12\%, vaginal 18\%) (Table $3)$. 
Table 4: Mean and median cervical dilation $(\mathrm{mm})$ with standard deviation/range.

\begin{tabular}{|c|c|c|c|c|c|c|}
\hline & Mean (mm) & Standard deviation & Median (mm) & Range (mm) & $\mathrm{T}$ & $\mathbf{P}$ \\
\hline Oral $(n=50)$ & 8.0 & 1.90 & 8.0 & $3-12$ & \multirow{2}{*}{0.598} & \multirow{2}{*}{$0.551 \mathrm{NS}$} \\
\hline Vaginal $(\mathrm{n}=50)$ & 8.2 & 1.41 & 8.0 & $4-12$ & & \\
\hline
\end{tabular}

Mean cervical dilatation in mm was 8.0 (1.9) and 8.2 (1.4) in oral and vaginal group respectively, which is not a statistically significant difference $(\mathrm{t}=0.598, \mathrm{p}=0.55)$ (Table 4).

Table 5: Distribution of gestational age and mean cervical dilation (mm)-MCD.

\begin{tabular}{|llllllll|}
\hline \multirow{2}{*}{$\begin{array}{l}\text { Gestational } \\
\text { age }(\text { wks) }\end{array}$} & \multicolumn{2}{l|}{ Oral $(\mathbf{n = 5 0})$} & \multicolumn{4}{c|}{ Vaginal $(\mathbf{n = 5 0})$} \\
\hline$<8$ & N & MCD & SD & N & MCD & SD \\
\hline 8 to $<10$ & 22 & 7.68 & 1.86 & 22 & 7.81 & 0.96 \\
\hline $10-12$ & 17 & 8.11 & 1.83 & 15 & 8.26 & 1.62 \\
\hline P value & 11 & 8.45 & 2.11 & 13 & 8.76 & 1.69 \\
\hline & 50 & 8 & 1.9 & 50 & 8.2 & 1.41 \\
\hline
\end{tabular}

In oral misoprostal group, mean cervical dilatation was $8.45 \mathrm{~mm}$ in patients with gestational age $10-12$ weeks followed by $8.11 \mathrm{~mm}$ in $8-10$ weeks and $7.68 \mathrm{~mm}$ in $<8$ weeks of period of gestation. Significant statistical difference was not seen $(\mathrm{p}=0.53)$.

Similarly, in vaginal group, mean cervical dilation was $8.76 \mathrm{~mm}$ in patients gestational age 10-12 weeks followed by $8.26 \mathrm{~mm}$ in $8-10$ weeks and $7.81 \mathrm{~mm}$ in $<8$ weeks of gestation $(\mathrm{p}=0.16)$. Significant statistical difference was not seen (Table 5).

GI side effects were more with oral misoprostol than vaginal misoprostol as shown in the table, but not statistically significant ( $\mathrm{p}$ value $>0.05$ ) except nausea for which the difference is significant $(\mathrm{p}=0.01)$.

Table 6: Distribution of patients according to side effects.

\begin{tabular}{|c|c|c|c|c|c|c|c|c|}
\hline \multirow{3}{*}{ Side effects } & \multicolumn{4}{|c|}{ Group } & \multirow{3}{*}{ Odds ratio } & \multirow{3}{*}{$\begin{array}{l}95 \% \\
\text { confidence interval }\end{array}$} & \multirow{3}{*}{$\begin{array}{l}\text { Chi } \\
\text { square value }\left(x^{2}\right)\end{array}$} & \multirow{3}{*}{$\begin{array}{l}\text { 'p' } \\
\text { value }\end{array}$} \\
\hline & \multicolumn{2}{|c|}{ Oral (50) } & \multicolumn{2}{|c|}{ Vaginal (50) } & & & & \\
\hline & $\mathbf{N}$ & $\%$ & $\mathbf{N}$ & $\%$ & & & & \\
\hline Nausea & 22 & 44 & 10 & 20 & 0.32 & $0.13-0.76$ & 6.62 & $0.01 \mathrm{NS}$ \\
\hline Vomiting* & 3 & 6 & 0 & 0 & 0.49 & $0.40-0.60$ & $*$ & $0.24 \mathrm{NS}$ \\
\hline Diarrhea* & 5 & 10 & 0 & 0 & 0.47 & $0.38-0.59$ & $*$ & $0.06 \mathrm{NS}$ \\
\hline Abdominal pain & 35 & 70 & 28 & 56 & 0.55 & $0.24-1.20$ & 2.10 & $0.15 \mathrm{NS}$ \\
\hline Vaginal bleeding & 18 & 36 & 20 & 40 & 0.19 & $0.53-2.66$ & 0.17 & $0.68 \mathrm{NS}$ \\
\hline Shivering & 3 & 6 & 1 & 2 & 0.32 & $0.03-3.18$ & 1.04 & $0.31 \mathrm{NS}$ \\
\hline Fever & 2 & 4 & 2 & 4 & 1.00 & $0.14-7.40$ & 0 & $1 \mathrm{NS}$ \\
\hline Total & 50 & & 50 & & *Fishers exa & t test & & \\
\hline
\end{tabular}

Vaginal bleeding and shivering is slightly more in vaginal group than oral but there was no statistical significant difference found ( $\mathrm{p}$ value $>0.05$ ) (Table 6).

\section{DISCUSSION}

In present study, we have selected pretreatment interval of 3 hours. Since when tablet misoprostol was given orally the plasma concentration increased rapidly and reached peak value between 12.5 minutes to 60 minutes and decreased steeply by 120 minutes and remained at lower concentration whereas when the same tablet was kept inside the vagina the peak level of the drug achieved between 60-120 minutes and decreased slowly. ${ }^{5}$
Table 7: Comparison of patients with respect to age, period gestation, parity and cervical dilation.

\begin{tabular}{|llll|}
\hline & $\begin{array}{l}\text { Oral group } \\
(\mathrm{n}=50)\end{array}$ & $\begin{array}{l}\text { Vaginal } \\
\text { group }(\mathrm{n}=50)\end{array}$ & $\begin{array}{l}\mathrm{P} \\
\text { value }\end{array}$ \\
\hline Age (years) & $28.2(5.3)$ & $27.4(5.1)$ & $\begin{array}{l}\mathrm{P}-0.44 \\
\mathrm{NS}\end{array}$ \\
\hline $\begin{array}{l}\text { Gestation } \\
\text { (weeks) }\end{array}$ & $8.0(2.1)$ & $8.1(2.0)$ & $\begin{array}{l}\mathrm{P}-0.59 \\
\mathrm{NS}\end{array}$ \\
\hline $\begin{array}{l}\text { Primigravidae: } \\
\mathrm{n}(\%)\end{array}$ & $3(6 \%)$ & $3(6 \%)$ & - \\
\hline $\begin{array}{l}\text { Multigravidae: } \\
\mathrm{n}(\%)\end{array}$ & $47(94 \%)$ & $47(94 \%)$ & - \\
\hline $\begin{array}{l}\text { Cervical } \\
\text { dilation }(\mathrm{mm})\end{array}$ & $8.0(1.9)$ & $8.2(1.4)$ & $\begin{array}{l}\mathrm{P}-0.55 \\
\mathrm{NS}\end{array}$ \\
\hline
\end{tabular}


Fong et al showed that misoprostol tablet given 3 hours before suction aspiration was sufficient for pretreatment dilatation of cervix (Table 7). ${ }^{6}$

In present study, majority of the women in the oral misoprostol group were 26-30 years and 21-25 years in vaginal misoprostol group. The mean age was 28.2 and 28.4 respectively $(\mathrm{p}=0.44)$, which is comparable to Oppegaard K et al, Lawrie et al and MacIsaac L et al studies. ${ }^{7-9}$ But the mean age in Ashok PW et al and Ngai et al is not comparable because they selected only nulligravidae (Table 8). ${ }^{10,11}$

Table 8: Comparison of the age with other studies, values in mean (SD).

\begin{tabular}{|lllll|} 
& Group & & Vaginal & (Mean age years) \\
\hline & $\mathbf{n}$ & (Mean age years) & N & 27.4 (5.1) \\
\hline Present study. & 50 & $28.2(5.3)$ & 50 & $20.4(5.1)$ \\
\hline $\begin{array}{l}\text { Ashok et al, University Aberdeen, } \\
\text { U.K. }\end{array}$ & 32 & $20.1(4.5)$ & 32 & $22.2(4.7)$ \\
\hline $\begin{array}{l}\text { Ngai SW et al, Queen Mary } \\
\text { Hospital University of Honkong }\end{array}$ & 40 & $23.4(6.0)$ & 37 & $26.4(17-37)$ \\
\hline $\begin{array}{l}\text { Lawrie A et al, Aberdeen Maternity } \\
\text { Hospital, U.K. }\end{array}$ & 28 & $25.5(16-40)$ & 30 & $28.1(6.2)$ \\
\hline $\begin{array}{l}\text { Oppegaard K et al, Ulleval } \\
\text { University Hospital, Norway }\end{array}$ & 158 & $27.7(6.9)$ & 163 & $25.0(16-43)$ \\
\hline $\begin{array}{l}\text { Maclsaac L et al, University of } \\
\text { California, California }\end{array}$ & 45 & $23.0(16-39)$ & 47 & 2 \\
\hline
\end{tabular}

Table 9: Comparison of mean cervical dilation ( $\mathrm{mm})$ with other studies.

\begin{tabular}{|lllllll|}
\hline Group & Ashok PW et al & Ngai SW et al & Lawrie A et al & Oppegard K et al & Present study & Fong YF et al \\
\hline Oral & 7.0 & 7.2 & 6.9 & 6.2 & 8.0 & - \\
\hline Vaginal & 7.0 & 6.8 & 7.0 & 6.5 & 8.2 & 8.2 \\
\hline 'p' value & $\mathrm{P}=0.87$ & & & & & \\
\hline
\end{tabular}

Table 10: Comparison of side effects experienced by patients with other studies, values in percentage.

\begin{tabular}{|llllllllll|} 
& Ashok PW et al & & \multicolumn{2}{l}{ Ngai SW et al } & \multicolumn{2}{c|}{ Present study } \\
& Oral & Vaginal & Odds ratio & Oral & Vaginal & Oral & Vaginal & Odds ratio \\
\hline Nausea & 56 & 25 & 3.86 & 5 & 0 & 44 & 20 & $0.01 \mathrm{sig}$ \\
\hline Vomiting & 6 & 6 & 0.97 & 0 & 0 & 6 & 0 & $0.24 \mathrm{~ns}$ \\
\hline Diarrhea & 12 & 0 & 0.47 & 0 & 0 & 10 & 0 & $0.06 \mathrm{~ns}$ \\
\hline Abdominal pain & 69 & 62 & 1.21 & 20 & 21 & 70 & 56 & $0.15 \mathrm{~ns}$ \\
\hline Vaginal bleeding & 25 & 34 & 0.6 & 13 & 14 & 36 & 40 & $0.68 \mathrm{~ns}$ \\
\hline
\end{tabular}

Mean cervical dilatation in our study was slightly more than that of Ashok PW et al and Ngai SW et al. ${ }^{10,11}$ No significant statistical difference was found in both groups of tablet misoprostol. Mean cervical dilatation in various studies ranges from 6.2 to $8.2 \mathrm{~mm}$ (Table 9).

Tab misoprostol 400 microgram was given 3 hours prior to surgical abortion in both groups in present study, Ashok PW et al and Ngai SW et al where as it was 12 hours (oral group) and 3 hours (vaginal group) in Lawrie et al and Oppegaard $\mathrm{K}$ et al., ${ }^{71}$ There was a satisfactory preoperative cervical dilatation of $\geq 7 \mathrm{~mm} .{ }^{11,8}$ In current study, $90 \%$ in oral route group and $94 \%$ in vaginal route group had preoperative satisfactory dilatation of cervix $\geq 7 \mathrm{~mm}$ (Table 10). In present study nausea, vomiting, diarrhea and abdominal pain were more in oral than vaginal group but statistically not significant $(p>0.05)$ except nausea which is statistically significant $(\mathrm{p}=0.01)$.

Vaginal bleeding and shivering is slightly more in vaginal group than oral but there was no significant statistical difference $(\mathrm{p}>0.05)$. Present study was comparable with Ashok PW et al. However, studies of Lawrie A et al, Carbonel JL et al and Oppegaard et al and women in the Lawrie et al, study experienced severe pain and excessive bleeding preoperatively and incomplete abortion compared to vaginal route, as pretreatment interval was 12 hours (oral) and 3 hours (vaginal) with 400 microgram 
misoprostol. ${ }^{7}$ In Carbonel JL et al study oral group experienced more gastrointestinal side effects as they gave 400 microgram misoprostal $8 \mathrm{hrs}$ prior to surgical abortion in oral group, in contrast to $2-4 \mathrm{hrs}$ in vaginal group. ${ }^{12}$

Present study has showed that oral tab misoprostol 400 micrograms given orally 3 hours before surgical abortion has similar efficacy and no significant difference in the side effects compared to vaginal misoprostol with same pretreatment interval.

\section{CONCLUSION}

Present study concluded that either oral or vaginal tab misoprostol 400 microgram given 3 hours before as a priming agent was resulted in effective dilatation of the cervix. Oral route is an effective alternative to vaginal route. Oral route is preferred over vaginal route because women can do self-administration at home and there was no internal examination discomfort. For doctors and Nursing staff it reduces the work load especially in day care settings.

Funding: No funding sources Conflict of interest: None declared

Ethical approval: The study was approved by the Institutional Ethics Committee

\section{REFERENCES}

1. Grimes DA, Schulz KF, Cates Jr WJ. Prevention of uterine perforation during curettage abortion. JAMA 198;2511(16):2108-11.

2. Schulz KF, Grimes DA, Cates Jr W. Measures to prevent cervical injury during suction curettage abortion. Lancet. 1983;1(8335):1182-5.

3. Royal College of Obstetrics and Gynecologist. Clinical effectiveness support unit. the care of women requesting induced abortion. London: RCOG Press; 2000.

4. Ashok PW, Flett GM, Temploton A. Mifepristone versus vaginally administered misoprostol for cervical ripening before first trimester termination of pregnancy: a randomized controlled study. Am J Obstet Gynecol. 2000;183(4);998-1002.

5. Zieman M Fong SK, Benowitz NL, Banskter and Carney P D. Absorption Kinetics of misoprostol with oral or vaginal administration. Obstet Gynecol. 1997;90:88-92.

6. Fong YF, Singh K, Prasad RN. A comparative study using Two dose regimens of vaginal misoprostol for preabortive cervical dilatation in the first trimester nulliparae. Br J Obstet Gynecol. 1998;105(4):413-7.

7. Lawrie A, Penny G, Templeton A. A randomized comparison of oral and vaginal misoprostol for cervical priming before suction termination of pregnancy. Br J Obstet Gynecol. 1996;103(11):11179.

8. Oppegaard K, Quigstad E, Nesheim B. Oral versus self-administered vaginal misoprostol at home before surgical termination of pregnancy a randomized controlled trial. Br J Obstet Gynecol. 2006;113:5864.

9. Mac Isaac L, Grossman D, Balistreri E, Carney P. A randomized controlled trial of Laminaria, oral misoprostol and vaginal misoprostol before abortion. Obstet Gynecol. 1999;93:766-70.

10. Ashok PW, Hamoda H, Nathani F, Flett GM, Templeton A. Randomized controlled study comparing oral and vaginal misoprostol for cervical priming prior to surgical termination of pregnancy. Br J Obstet Gynecol. 2003;110:1057-61.

11. Ngia SW, Chan YM, Tang OS, Lao T, Ho PC. The use of misoprostol for preoperative cervical dilatation prior to vacuum aspiration: a randomized trial. Him Repord. 1999;14(8):2139-42.

12. Carbonel JL, Velazco A, Rodriguez Y. Oral versus vaginal misoprostol for cervical priming in first trimester abortion: A randomized trial. Eur J Contracept Report Health Care. 2001;6(3):134-140.

Cite this article as: Revankar VM, Harsha TN.

Tablet misoprostol as a cervical priming agent prior to surgical abortion. Int J Reprod Contracept Obstet Gynecol 2017;6:3004-8. 